Max A. Chernesky PH D, Ron A. Browne MD FRCP(C), Peter Rondi MD FRCP(C)

\title{
Hepatitis B virus antibody prevalence in anaesthetists
}

The prevalence of antibodies to hepatitis $B$ virus (anti HBs or anti HBC) was 36.9 per cent in a group of anaesthetists, campared to 3.7 per cent in volunteer blood donors and 5.6 per cent of patients without hepatic infections. Professional risk factors such as treating a hepatitis B patient or working in a hospital laboratory, haemodialysis, an intensive care unit, or in oncology, did not correlate with antibody prevalence. Personal risk factors sach as a history of a family member with hepatitis, or of receiving blood transfusion in the past were aiso not associated. A greater number of anaesthetists with a history of hepatitis in the past had antibodies, than those with no history $(p<0.05)$. The country of origin may have been a contributing factor to antibody prevalence as highest positivity rates were found in subjects from Asia, Africa and Eastern Europe. One of 31 (3.2 per cent) seronegative subjects seroconverted over a four-year period. Results of testing in 1978 and 1982 revealed that 37 per cent of immune subjects possessed only anti $H B C$ and at least one person positive for both markers on the first occasion was only anti HBc positive later. Laboratory testing, risk factors, and immunization for $\mathrm{HBV}$ should be examined in greater detail in larger populations of health care workers.

Key words

LIVER: hepatitis, hepatitis B virus, antibody to hepatitis B surface antigen (anti HBs), antibody to hepatitis $B$ core antigen (anti $\mathrm{HBc}$ ), risk factors.

From the Departments of Paediatrics, Pathology and Anaesthesia, Faculty of Health Sciences, McMaster University, Hamilton, Ontario.

Address correspondence to: Dr. M.A. Chernesky, McMaster University Regional Virology Laboratory, St. Joseph's Hospital, Harrilton, Ontario, Canada, L8N 4A6.
Anaesthetists ${ }^{1-3}$ as well as other hospital personnel ${ }^{4-14}$ may be at risk of acquiring hepatitis $B$ virus (HBV) from occupational exposure. The prevalence of antibodies to HBV-hepatitis B surface antibody (anti HBs) and anti core (anti $\mathrm{HBc}$ ) varies in different population groups ${ }^{15}$ and is influenced by several risk factors including population asymptomatic carrier rates of hepatitis B surface antigen. ${ }^{16}$ The asymptomatic carrier rate of HBsAg has been determined in Canada as 0.54 per cent ${ }^{17}$ and studies have determined anti $\mathrm{HB} s$ prevalence rates in Canadian populations. ${ }^{5,6}$

A survey by questionnaire ${ }^{4}$ to determine the frequency of hepatitis in medical specialists in Ontario revealed that surgeons had the highest percentage ( 12.2 per cent) of a history of hepatitis, whereas radiologists had the lowest (5.0 per cent). In that survey 10.5 per cent of anaesthetists recorded a history of hepatitis. In anticipation of the licensure of hepatitis B vaccine, we initiated a study in 1978 to cetermine the prevalence of antibodies to $\mathrm{HBV}$ and attempted to correlate risk factors in a group of anaesthetists practicing in teaching hospitals in Hamilton and Burlington, Ontario, Canada. The study was repeated in 1982.

\section{Methods}

\section{Population surveyed}

All anaesthetists and some trainees (total 53), working in six teaching hospitals in Hamilton and Burlington, Ontario, Canada anonymously submitted $5 \mathrm{ml}$ of clotted blood in 1978 and 1982 . A questionnaire asked for age, sex, years of anaesthetic practice, history of hepatitis or blood transfusion, family history of hepatitis, country of origin, experience in hospital laboratories, haemodialysis, oncology or intensive care.

Sera from 53 volunteer blood donors (age- and sex-matched to the 1978 population) were acquired from the Hamilton Branch of the Canadian Red 
TABLE I Prevalence of antibodies* to hepatitis B virus in a population of anaesthetists, volunteer blood donors and the general population, Hamilton, Ontario, Canada, 1978

\begin{tabular}{|c|c|c|c|c|c|}
\hline \multirow[b]{2}{*}{ Age group } & \multicolumn{2}{|c|}{ Sex } & \multirow[b]{2}{*}{ Blood donors } & \multirow{2}{*}{$\begin{array}{l}\text { General } \\
\text { population }\end{array}$} & \multirow[b]{2}{*}{ Anaestherists } \\
\hline & $M$ & $F$ & & & \\
\hline $20-29$ & 4 & 2 & 0 & $1(16)$ & 0 \\
\hline $30-39$ & 19 & 3 & $1(4.5) \dagger$ & $1(4.5)$ & $4(13)$ \\
\hline $30-49$ & 8 & 2 & 0 & $\mathrm{l}(10)$ & $1(10)$ \\
\hline $50-59$ & 8 & 1 & $1(11)$ & D & $1(11)$ \\
\hline $60-69$ & 6 & 0 & 0 & 0 & $2(33.3)$ \\
\hline \multirow[t]{2}{*}{ Total } & 45 & 8 & $2(3.7)$ & $3(5.6)$ & $8(15.0)_{+}^{+}$ \\
\hline & \multicolumn{2}{|c|}{53} & & & \\
\hline
\end{tabular}

*Tested for antibodies to surface antigen (anti HBs) and to core antigen (anti HBc). $¥$ Number in parentheses denotes per cent positive for anti HBs.

fDifference in prevalence of anti HBs in blood donors, general population, and anaesthetists in 1978 had a $\chi^{2}$ value of 5.19 on $2 \mathrm{df}, \mathrm{p}=0.07$.

Cross Blood Transfusion Service (CRCBTS). This service has a long list of exclusions and deferrals of blood for transfusion including that from persons with cancer, jaundiced, with kidney disease, polycythemia, hepatitis contact within 12 months, recent infectious mononucleosis, etc. Sera from 53 patients submitted to the Regional Virology Laboratory for serological analysis of infections determined from clinical history not to have involved hepatic disease were also age-and sex-matched as a further control group.

\section{Laboratory tests}

All sera were tested for anti $\mathrm{HBs}$ and anti $\mathrm{HBc}$ by solid phase radioimmunoassay (RIA), AUSAB and CORAB (Abbott Laboratories, n. Chicago). ${ }^{18,19} \mathrm{~A}$ positive value was defined as recommended by the manufacturer. Anti HBs titers were calculated using criteria of 2.1 ratio units (RU) and $10 \mathrm{RU}$.

Statistical analysis

Statistical analysis was performed by Chi square and reported at various $p$ values.

\section{Results}

In 1978,15 per cent of the anaesthetists possessed either anti HBs or anti HBc in their sera (Table I). A group of age- and sex-matched volunteer blood donors had an overall antibody prevalence rate of 3.7 per cent, whereas 5.6 per cent of matched patients who were being investigated for other non-hepatic illnesses demonstrated antibody in their specimens. There were no differtences exhibited between males and females in the three populations. When the survey of anaesthetists was repeated in 1982,35 of the original 53 were available for tcsting and an additional 18 physicians had entered the system during this four-year period. Because the conditions of testing in both years were identical and no factors in the community could be determined which might influence prevalence rates over the four-year period, results of the 53 original assays were grouped with the result: of testing the 18 new annesthetists to provide a larger group for analysis of risk factors. Table II shows the prevalence of antibodies in anaesthetist s according to years in practice. In each year studied, high per cent positivity rates were observed in physicians who

TABLE II Prevalence of antibodies to HBV" in anaesthetisı according to years in practice

\begin{tabular}{clll}
\hline Years in practice & 1978 & 1982 & Both years \\
\hline $0-9$ & $5 / 20 \dagger(25) \ddagger$ & $3 / 24(12.5)$ & $6 / 35(17)$ \\
$10-19$ & $0 / 18(0)$ & $2 / 9(22.2)$ & $1 / 20(5)$ \\
$20-29$ & $1 / 3(12.5)$ & $2 / 14(14.2)$ & $3 / 10(30)$ \\
$30-40$ & $2 / 7(28.5)$ & $1 / 6(16.6)$ & $2 / 6(33)$ \\
Total & $8 / 53(15.0)$ & $8 / 53(15.0)$ & $12 / 71(16.9)$ \\
\hline
\end{tabular}

*Tested for anti $\mathrm{HBs}$ and anti $\mathrm{HBC}$.

$\dagger$ Number positive aver number in the group.

$¥$ Per cent positive in the group.

$\$ 53$ from 1978 plus 18 new members in 1982.

Tests of significance not done because of small sample size on independent data of four groups of years in practice. 
TABLE III Role of personal risk factors to the prevalence of antibodies to HBV* in 71 anaesthetists

\begin{tabular}{|c|c|c|c|c|c|c|}
\hline \multirow[b]{2}{*}{ Risk factor } & \multirow[b]{2}{*}{ History } & \multirow[b]{2}{*}{ No. in group } & \multicolumn{4}{|c|}{ Totat $(71) \dagger$} \\
\hline & & & anti $H B s$ & $\%$ & $x^{2}$ & $p$ \\
\hline Hepatitis in past & $\begin{array}{l}\text { Yes } \\
\text { No }\end{array}$ & $\begin{array}{r}5 \\
65\end{array}$ & $\begin{array}{l}3 \\
9\end{array}$ & $\begin{array}{l}50.0 \\
1.38\end{array}$ & 5.11 & 0.05 \\
\hline Family member with & & & & & & \\
\hline hepatitis in past & $\begin{array}{l}\text { Yes } \\
\text { No }\end{array}$ & $\begin{array}{l}13 \\
58\end{array}$ & $\begin{array}{r}1 \\
11\end{array}$ & $\begin{array}{r}7.7 \\
19.0\end{array}$ & 0.96 & 0.50 \\
\hline $\begin{array}{l}\text { Received blood transfusion } \\
\text { in past }\end{array}$ & $\begin{array}{l}\text { Yes } \\
\text { No }\end{array}$ & $\begin{array}{r}5 \\
66\end{array}$ & $\begin{array}{r}1 \\
11\end{array}$ & $\begin{array}{l}20.0 \\
16.7\end{array}$ & 0.36 & 0.70 \\
\hline
\end{tabular}

*Tested for anti HBs and anti $\mathrm{HBC}$.

†Population number.

had been in practice for $30-40$ years. The high positivity rate in the lower age groups is interesting and may be a reflection of the inherent problems of analyzing small numbers. In the combined data all seven positive anaesthetists who were in practice ten years or less were from foreign countries, whereas the three Canadian physicians had practiced longest. There is a suggestion of a trend to an increase in positivity with an increase in years of anaesthetics practice.

Table III summarizes the role of personal risk factors to the prevalence of antibodies. Although a positive history of having a family member with hepatitis or having received a blood transfusion in the past appeared to indicate increased risk for antibody prevalence in one or other of the two years surveyed, differences were not consistent between the two surveys. When the 71 subjects are analyzed a larger percentage of physicians with antibody had a positive history of hepatitis ( 50.0 per cent) than those who had a negative history (13.8 per cent) $(\mathrm{p}<0.05)$.

Table IV summarizes the role of professional factors which might place anaesthetists at risk to HBV infection. It appears from the data that treating a known $\mathrm{HB}$ patient or working in a hospital laboratory, haemodialysis, an intensive care unit or oncology presented no increased risk to seroconversion.

TABLE IV Role of professional risk factors to the prevalence of antibodies to HBV* in 71 anaesthetists

\begin{tabular}{|c|c|c|c|c|c|c|}
\hline \multirow[b]{2}{*}{ Risk factor } & \multirow[b]{2}{*}{ History: } & \multirow[b]{2}{*}{ No. in group } & \multicolumn{4}{|c|}{ Tota' $(7 I) \dagger$} \\
\hline & & & anti $\boldsymbol{H} \boldsymbol{B}$. & $\%$ & $x^{2}$ & $p$ \\
\hline \multicolumn{7}{|l|}{ Worked on known } \\
\hline HB patient & $\begin{array}{l}\text { Yes } \\
\text { No }\end{array}$ & $\begin{array}{l}45 \\
26\end{array}$ & $\begin{array}{l}9 \\
3\end{array}$ & $\begin{array}{l}20.0 \\
11.5\end{array}$ & 0.84 & 0.50 \\
\hline \multicolumn{7}{|l|}{ Worked in hospital } \\
\hline laboratory & $\begin{array}{l}\text { Yes } \\
\text { No }\end{array}$ & $\begin{array}{l}22 \\
49\end{array}$ & $\begin{array}{r}0 \\
12\end{array}$ & $\begin{array}{l}0 \\
24.5\end{array}$ & 6.48 & 0.02 \\
\hline Worked in haemodialysis & $\begin{array}{l}\text { Yes } \\
N_{0}\end{array}$ & $\begin{array}{l}11 \\
60\end{array}$ & $\begin{array}{r}2 \\
10\end{array}$ & $\begin{array}{l}18.2 \\
16.7\end{array}$ & 0.01 & 0.95 \\
\hline Worked in intensive care & $\begin{array}{l}\text { Yes } \\
\text { No }\end{array}$ & $\begin{array}{l}58 \\
13\end{array}$ & $\begin{array}{r}11 \\
1\end{array}$ & $\begin{array}{r}19.0 \\
7.7\end{array}$ & 0.96 & 0.50 \\
\hline Worked in oncology & $\begin{array}{l}\text { Yes } \\
\text { No }\end{array}$ & $\begin{array}{r}5 \\
66\end{array}$ & $\begin{array}{r}1 \\
11\end{array}$ & $\begin{array}{r}3.7 \\
19.0\end{array}$ & 0.36 & 0.70 \\
\hline
\end{tabular}

"Tested for anti HBs and anti HBc.

$\uparrow$ Population number. 
TABLE V HBV antibody* positives according to countries of origin of 71 anaesthetists

\begin{tabular}{lccl}
\hline Countries & Number & Posiives & $\%$ \\
\hline Asia - east & 7 & 2 & $(28.6)$ \\
$\quad-$ middle & 3 & 1 & $(33.3)$ \\
Australia & 1 & 0 & $(0)$ \\
Canada & 44 & 3 & $(6.8) \dagger$ \\
Europe - east & 4 & 2 & $(50)$ \\
Scandinavia & 1 & 0 & $(0)$ \\
Africa & 2 & 2 & $(100)$ \\
United Kingdom & 7 & 2 & $(28.6)$ \\
West Indies & 2 & 0 & $(0)$ \\
$\quad$ Total & 71 & 12 & \\
\hline
\end{tabular}

${ }^{*}$ Tested for anti HBs and anti HBc.

† Significantly lower than positives in foreign anaesthetists ( 9 of 27 ) $33 \%$ ( $p<0.001)$.

Table $V$ summarizes the antibody positives according to countries of origin. Two were from east Asia, one from India, three from Canada, two from Poland, two from Africa and two from England. Only three of 44 (6.8 per cent) Canadian born anaesthetists were positive as opposed to nine of 27 (33.3 per cent) from foreign countries ( $p<0.001$ ). The per cent positivity rate in Canadian born physicians in this study is approximately the same as that found in the control population (5.6 per cent). Thus in this group of anaesthetists, country of origin may have been a major factor in acquisition of antibodies to HBV.

Table VI summarizes the risk factors of the 12 positive physicians in the survey. They were berween

TABLE VI Summary of risk factors of $12 \mathrm{HBV}$ antibody positive anacsthetists

\begin{tabular}{lccll}
\hline Anaesthetist & Age & $\begin{array}{l}\text { Years of } \\
\text { practice }\end{array}$ & $\begin{array}{l}\text { Hepatisis } \\
\text { in past }\end{array}$ & $\begin{array}{l}\text { Coundy of } \\
\text { origin }\end{array}$ \\
\hline 1 & 30 & 3 & No & Ghana \\
2 & 30 & 5 & No & South Africa \\
3 & 31 & 4 & Yes & India \\
4 & 32 & 4 & No & Hong Kong \\
5 & 37 & 9 & No & U. Kingdom \\
6 & 37 & 10 & No & U. Kingdom \\
7 & 45 & 6 & Yes & Poland \\
8 & 51 & 21 & No & Paland \\
9 & 54 & 20 & No & Hong Kong \\
10 & 56 & 25 & No & Canada \\
11 & 63 & 30 & Yes & Canada \\
12 & 63 & 30 & No & Canada \\
\hline
\end{tabular}

TABLE VII Hepatitis $B$ antibody status of anaesthetists to surface antigen (anti HBs) and corc antigen (anti HBc)

\begin{tabular}{lllll}
\hline \multicolumn{5}{c}{ HBV Markers } \\
\cline { 2 - 5 } Year & Anti HBs & Anti HBc & Both & Totals \\
\hline 1978 & 5 & 0 & 3 & 8 \\
1982 & 4 & 3 & 1 & 8 \\
\hline
\end{tabular}

30 and 65 years of age and only three reported that they had had hepatitis in the past. These were not grouped into a particular age bracket. Analysis of the relationship between years of practice and positive markers which was high in the 0-9 group (Table ll) showed in Table VI that all were from foreign countries. Alternatively all three Canadian born physicians had been in practice for 25 to 30 years.

Table VII summarizes results of serological testing. In 1978, five anaesthetists possessed only anti HBs and three had both markers. Of the original eight antibody positives in 1978 , four were again positive in 1982 and the other four had left the area (two had both markers and two who only had anti HBs). One person who was negatjve during 1978 seruconverted and was positive only for anti HBs in 1982 . Another physician who possessed both markers in 1978 had only anti $\mathrm{HBc}$ in 1982. A total of 18 physicians surveyed in 1978 were not available for study in 1982 . They were replaced by 18 new anaesthetists of whom one was positive for anti $\mathrm{HBs}$ and two were positive for anti HBc only. All eight positive subjects in 1978 demonstrated anti HBs, whereas in 1982 only five had anti HBs and three possessed only anti HBc in their sera. Thus, although the anti HBs test detected all positives in 1978 , in 1982, three of eight ( 37 per cent) positives would have been missed without testing for anti HBc. Each person positive for anti $\mathrm{HBc}$ and negative for anti HBs was tested again three months later and yielded similar results.

\section{Discussion}

This study, which surveyed anaesthetists for the prevalence of HBV antibodies (anti HBs and anti $\mathrm{HBc}$ ), adds to the published literature of serological prevalence rates in Canadian health care worker populations (Table VII). Volunteer blood donors whose blood is highly selected with many reasons 
TABLE VIII Prevalence of antibody to hepatitis B virus in various selected Canadian populations

\begin{tabular}{|c|c|c|c|}
\hline Population & No. studied & Fositive & Reference \\
\hline Volunteer blood donors & 53 & 3.7 & present study \\
\hline General population (all ages) & 53 & 5.6 & present study \\
\hline (summer students) & 46 & 0 & Bishai et al 1977 \\
\hline (women) & 1483 & $2.9-6.9$ & Bishai er al. 1977 \\
\hline \multirow[t]{2}{*}{ Administrative and clerical hospital staff } & 34 & 0 & Bishai ef al. 1977 \\
\hline & 116 & $6.1-14.3$ & Leers et al. 1973 \\
\hline \multirow[t]{2}{*}{ Medical students, interns, residents } & 31 & 0 & Leers et al. 1973 \\
\hline & & 0 & Bishaj et al. 1973 \\
\hline Nurses & 182 & $11.2-14.0$ & Leers et al. 1973 \\
\hline Anaesthetjsts & 71 & 16.9 & present study \\
\hline Laboratory technologists (general) & 123 & 20.3 & Leers et al. 1973 \\
\hline (general) & 181 & $11.6-130$ & Bishati et al 1977 \\
\hline (chemistry) & 28 & 43.0 & Bishai et al. 1977 \\
\hline (chemistry) & 25 & 40.0 & Leers ef al. 1973 \\
\hline (hatenatology) & 25 & 32.0 & Leers et al. 1973 \\
\hline (microbiology) & 24 & 20.8 & Leers $e$ t al. 1973 \\
\hline (pathology) & 17 & 0 & Leers et al. 1973 \\
\hline (pathology) & 56 & 9.0 & Bishai et al. 1977 \\
\hline Pathologists and laboratory scientists & 15 & 26.6 & Bishai et al. 1977 \\
\hline Haematologists and phlebotomists & 31 & 32.2 & Bishai et al. 1977 \\
\hline Renal dialysis staff & 50 & 16.0 & Bishai et al. 1977 \\
\hline Institutions for mentally retarded (staff) & 120 & 12.5 & Bishai et al. 1977 \\
\hline (patients) & 70 & 44.3 & Bishai et al. 1977 \\
\hline
\end{tabular}

for exclusion had a low prevalence rate of 3.7 per cent. Our general population which was sex- and age-matched possessed a 5.6 per cent rate which is comparable to other groups analyzed by $\mathrm{Bishai}^{4}$ in Canadian nonhospital personnel (2.9-6.9 per cent) and by Lewis ${ }^{12}$ in similar subjects in the United States ( 8.7 per cent). Canadian Red Cross volunteer blood donors at a per cent prevalence rate of 3.7 are much lower than that reported by Lander et $\mathrm{al}^{1}{ }^{17}$ in the U.S.A. for volunteer blood donors (14.4 per cent) and commercial donors (22.6 per cent), and may be a reflection of the stringent regulation of donor blood by the CRCBTS (see Methods).

In each of the two years studied the anaesthetists' prevalence rate was 15 per cent, with a 16.9 per cent rate when the studies are combined. In a similar study performed in South Africa ${ }^{1}$ the prevalence rate was 17.9 per cent. A nationwide seroepidemiological survey ${ }^{6}$ performed in the U.S.A. in 1975 and 76 which tested 59 anaesthetists, yielded a per cent positivity rate of 17 per cent. More recently Berty et al. ${ }^{3}$ reported a 23.3 per cent positivity rate for hepatitis $B$ markers. Thus all of these studies are similar in prevalence rates for the speciality of anaesthesia, although the most recent study ${ }^{3}$ included HBsAg as a marker which may be a reason for the higher prevalence. Accordingly, anaesthetists appear to fall into an intermediate risk group (Table VII), with their colleagues in surgery and laboratory medicine possessing higher antibody prevalence rates.

Antibody prevalence rates in our study are similar to those published from South Africa ${ }^{1}$ where the chronic carrier rate in the general population is quite different ( 0.54 per cent in Canada and 9 per cent in South Africa). The South African group of anaesthetists was made up of 83 whites, nine Asians, two Eurafricans and one Black subject, making it similar in race proportions to the Canadian group. Although anaesthetists in South Africa would theoretically be exposed more often to chronic carriers of HBsAg both studies were similar in antibody prevalence suggesting that this particular risk factor may not play a major role in determining seroconversion rates.

Although a history of hepatitis in out group indicated this as a personal risk factor for antibody prevalence, only 50 per cent of anaesthetists giving a history of hepatitis had antibodies. This was found in the South African study and in studies of other groups and may be accounted for by other viral and non-viral causes of hepatitis. 
Of great interest was the relationship of antibody prevalence to country of origin. Anaesthetists with antibody originated from Africa, Asia, Eastcm Europe, Canada and the United Kingdom (Table VI). Analysis of percentage positivity rates according to countries of origin (Table V) indicated highest rates in subjects from Asia, Africa and Eastern Europe where population antibody rates and $\mathrm{HBsAg}$ chronic carrier rates are relatively high. ${ }^{15}$ Thirty-three per cent of foreign born anaesthetists had positive markers as opposed to 6.8 per cent in those born in Canada. The rate in Canadians approximates that found in our general population.

Berry et $a .^{3}$ studying anaesthesia personnel in the U.S.A. showed a positive relationship between HBV markers and years since graduation. Nationality or country of origin was not addressed in that study. In our study the fact that all positive anaesthetists with ten or less years of practice were from foreign countries, suggests that country of origin contributed strongly to antibody positivity rates. Similarly the finding that all three positive Canadians had been in practice for $25-30$ years suggests a possible relationship between years in practice and the prevalence of HBV positive markers. Since the rate of positivity of these three is no higher than that in the general population and because the numbers are small no conclusions can be drawn.

It was interesting to leam that three of eight positives in 1982 were positive for anti $\mathrm{HBc}$ and not anti HBs and that one of these subjects had been positive for anti $\mathrm{HBs}$ and negative for anti $\mathrm{HBc}$ in 1978, suggesting that, in this particular study and in similar studies involving small specialty health care groups, more accurate results of prevalence rates will be obtained by analyzing sera for both markers. Grady ${ }^{1}$ found smaller rates of marker exclusiveness in analyzing large numbers of hospital workers.

It appears from this study that anacsthetists possess an intermediate prevalence of antibodies to $\mathrm{HBV}$ and that this rate is influenced by personal risk factors such as country of origin and professional risk factors such as years in practice may be contributory. A history of hepatitis (which may be a result of personal factors or risk of the profession) is only 50 per cent predictive of antibody prevalence. The fact that over a four-year period only one of 31 ( 3 per cent) anaesthetists seroconverted suggests that the risk of infection in this group of health care workers is low. However, more conclusive evi- dence to support this suggestion will only be possible through a larger prospective study.

\section{Acknowledgements}

We thank the CRCBTS Hamilton Branch for providing sera. We appreciate the co-operation of the anaesthetists in the region and Dr. H.S. Shannon for biostatistical advice. St. Joseph's Hospital Foundation provided funding which enabled the study to be performed.

\section{References}

1 Carstens J, MacNab GM, Kew MC. Hepatitis-B virus infection in anaesthetists. Br J Anaesth 1977; 49: 887-9.

2 Waterson AP. Hepatitis B as a hazard in anaesthẹtic practice. Br J Anaesth 1976; 48: 21-4.

3 Berry AJ, Isaacson $W$, Hunt $D$ et al. The prevalence of hepatitis $B$ in anesthesia personnel. Anesthesiology 1982: 57: A448.

4 Berris $B$, Feinman $S V$, Sinclair JC et al. Frequency of hepatitis in specialists in Ontario. Can J Public Health 1975; 66: 468-70.

5 Bishai FR, MacMillan S, Dempster G, Rhodes AJ, Spence $L$, Wrobel DM. Frequency of hepatitis $B$ surface antibody (anti-HBs) in various Canadian populations as measured by modified solic-phase radioimmunoassay. Can J Microbiol 1977: 23: 92-9

6 Leers W-D, Kouroupis GM. Prevalence of hepatitis $B$ antibodics in hospital personnel. Can Med Assac J $1975 ; 113 ; 844-7$.

7 Denes AE, Smith JL, Maynard JE, Doto IL, Berquist. $K R$, Finkel $A J$. Hepatitis $B$ infection in physicians. JAMA 1978; 239: 210-2.

8 Rosenberg $J L$, Jones DP, Lipir LR, Kirsner JB. Vira hepatitis: An occupational hazard to surgeons. JAMA 1973; 223: 395-400.

9 Trumbull ML, Greiner DJ. Homologous scrum jaundicc. An occupational hazard to medical personnel. JAMA 1951; 145: 965-7.

10 Pattison CP, Maynard JE, Berquist KR, Webster $H M$. Epidemiology of hepatitis B in hospital personnel. Am J Epidemiol 1975; 101: 59-64.

11 Dienstag $J L, R y a n$ DM. Occupational exposure to hepatitis $B$ virus in hospital personnel: Infection or immunization? Am J Epidemiol 1982; 115: 2639.

12 Grady $G F$. Hepatitis B immunity in hospital staff targeted for vaccination. JAMA 1982; 248: 22669. 
13 Lewis $T L$, Alter $J H$, Chaimers TC et al. A comparison of the frequency of hepatitis $B$ antigen and antibody in hospital and nonhospital personnel. N Engl J Med 1973; 298: 647-51.

14 Cherubin CE, Lander JJ, Purcell RH, McGinn $T G$, Cone $L A$. Acquisition of antibody to hepatitis B antigen in three socioeconomically different medical populations. Lancet 1972; ii: 149-51.

15 Deinhardt $F$, Gust ID. Viral hepatitis. Bull WHO 1982; 60: 661-91.

16 WHO Technical Report Series 602. Advances in Viral Hepatitis, Report of an Expert Committee 1977.

17 Wrobel DM, Fëmman V, Herris B, Sinclair JC. Frequency of hepatitis B antigen in blood donors. Can Med Assoc J 1973: 108: 570-2.

18 Lander JJ, Alier JH, Purcell RH. Frequency of antibody to hepatitis-associated antigen as measured by a new radioimmunoassay technique. $J$ Immunol 1971; 106: 1166-71.

19 Hoofnagle JH, Gerety RJ, Ni L, Barker LF. Antibody to hepatitis $B$ core antigen. A sensitive indicator of HBV replication. N Engl J Med 1974; 290: 1336-40.

\section{Résumé}

On a détecté des anticorps au virus de l'hépatite $B$ (anui HBs ou anti $\mathrm{HBC}$ ) chez 16.9 pour cent d'un groupe d'anesthésistes comparés à 3.7 pour cuent chez des donneurs de sang volontaires et 5.6 pour cent chez des patients sans signe d'infection hépatique. On n'a pas trouvé de corrélation entre la prévalence des anticorps et les facteurs de risques d'ordre professionnei tels que le fait d' avoir à traiter un patient porteur d' hépatite $B$ ou de travailler dans un laboratoire d' hôpital, en hémodialyse, en unité de soins intensifs ou en oncologie. De mème, des facteurs de risques plus personnels tels qu'un cas d'hépatice chez un proche de la famille ou le fail d'avoir reçu une transfusion dans le passé ne présentaient pas de corrélation. Les anesthésiologistes qui avaient une histoire d' hépatite dans leur passé étaient plus nombreux d̀ avoir des anticorps que ceux sans histoire d' héparite ( $p<$ 0.05). Le pays d'origine semble devoir être un facteur contributoire important à l'égard de la prévalence de l'anticorps. En effet, les raux les plus élevés ont ené trouvés chez des sujets originant de l'Asie, de l'Afrique et de l'Europe de l'est. L'analyse des résultass du dépistage de 1978 à 1982 a révélé ce qui suit: Un seul des 31 sujets classés négatifs en 78 était dépisté comme positif après quatre ans (3.2 pour cent).

Trente-sept pour cent des sujets classés immunisés possédaient seulement l'anticorps anti $H B c$ et au moin.s une personne d'abord identifiée comme possédant les deux types d"anticorps en 78 ne passédait plus que l'anti $H B c$ en 82. Les études sérologiques, les analyses de facteurs de risques et des programmes d'immunisation s'imposent et devraient être êtendus à de larges secteur. des travailleurs de la santé. 